\title{
Maternal and fetal outcome in jaundice complicating pregnancy: a prospective study
}

\author{
Swati Sharma, Rupa Aherwar*, Shashikala Jawade
}

Department of Obstetrics \& Gynaecology, Chirayu Medical College, Bhopal, India

Received: 27 January 2016

Accepted: 01 March 2016

*Correspondence:

Dr. Rupa Aherwar,

E-mail: ahirwar.rupa@gmail.com

Copyright: () the author(s), publisher and licensee Medip Academy. This is an open-access article distributed under the terms of the Creative Commons Attribution Non-Commercial License, which permits unrestricted non-commercial use, distribution, and reproduction in any medium, provided the original work is properly cited.

\begin{abstract}
Background: The objective of the study was to study maternal and fetal outcome in pregnancy complicated with jaundice.

Methods: 30 antenatal patients with clinical /laboratory evidence of Jaundice were selected for study in period between august 2014 to august 2015 .

Results: The peak age of incidence in our study was 21-25 years $(66.6 \%)$ and majority were primigravida $(66.6 \%)$. All cases were in third trimester of pregnancy, 93.3\% were unbooked, $73.3 \%$ were term, $60 \%$ were of lower socioeconomic status and $73.3 \%$ were urban. All patients presented with jaundice at time of admission. Pruritus was most common presenting symptom present in $60 \%$ of patients. Other presenting complaints were nausea, high BP, abdominal pain and petechiae. Viral Hepatitis was most important cause of jaundice in this study found in $46.7 \%$ of cases. Preeclampsia and ICP were other causes of jaundice in this study. Hepatitis B was the most common cause of acute hepatitis $(26.7 \%)$ and incidence of hepatitis E was $13.3 \%$ in our study. Maternal mortality was found in 1 case of hepatitis E complicated with hepatic encephalopathy and coagulopathy. $2 \%$ of these patients developed FHF. All patients were kept in ICU for intensive monitoring. PPH was most common maternal complication in $60 \%$ of patients. There was 1 maternal death in our study. Of 30 patients, 12 had spontaneous onset of labour. All delivered vaginally of which $8(26.7 \%)$ were preterm of which 2 died, 4(13.3\%) were IUFD, 12 (40\%) had fetal distress with meconium stained liquor, $5(16.6 \%)$ had PROM, $2(6.7 \%)$ had fetal growth restriction and $2(6.7 \%)$ delivered uneventfully.

Conclusions: Jaundice in pregnancy results in a very high perinatal as well as maternal morbidity and mortality, and requires an early diagnosis and careful management.
\end{abstract}

Keywords: Jaundice in pregnancy, Viral hepatitis

\section{INTRODUCTION}

Liver dysfunction during pregnancy is multifactorial in origin and diagnosis is often challenging. The key to maternal and fetal wellbeing is an early diagnosis and appropriate management.

Hepatic disorders complicate about $3 \%$ of all pregnancies and fall under various categories. ${ }^{1}$ First is a heterogeneous group of liver disorders that are unique to pregnancy and occur in patients with a previously healthy liver. These include intrahepatic cholestasis of pregnancy, acute fatty liver of pregnancy and liver dysfunction associated with hyperemesis gravidarum and preeclampsia. These conditions remit spontaneously in puerperium.

Secondly, pregnancy may occur in background of a preexisting liver disease e.g. chronic viral hepatitis and cirrhosis liver. Third category is of common viral diseases like acute viral hepatitis which may occur incidentally during pregnancy. The fourth situation is that 
of disorders which are probably related to pregnancy e.g. biliary tract disease and Budd-Chiari Syndrome.

Although still enigmatic, there have been recent interesting advances in understanding of these unique pregnancy-related liver diseases. Hyperemesis gravidarum is intractable, dehydrating vomiting in the first trimester of pregnancy; $50 \%$ of patients with this condition have liver dysfunction. Intrahepatic cholestasis of pregnancy is pruritus and elevated bile acids in the second half of pregnancy, accompanied by high levels of aminotransferases and mild jaundice. Maternal management is symptomatic with ursodeoxycholic acid; for the fetus, however, this is a high-risk pregnancy requiring close fetal monitoring and early delivery.

Severe preeclampsia itself is the commonest cause of hepatic tenderness and liver dysfunction in pregnancy, and $2 \%-12 \%$ of cases are further complicated by hemolysis $(\mathrm{H})$, elevated liver tests $(\mathrm{EL})$, and low platelet count (LP)-the HELLP syndrome. Immediate delivery is the only definitive therapy, but many maternal complications can occur, including abruptio placentae, renal failure, subcapsular hematomas, and hepatic rupture. Acute fatty liver of pregnancy is a sudden catastrophic illness occurring almost exclusively in the third trimester; microvesicular fatty infiltration of hepatocytes causes acute liver failure with coagulopathy and encephalopathy. Early diagnosis and immediate delivery are essential for maternal and fetal survival.

Pregnancy causes very few alterations in the results of standard liver tests. The aminotransferases (AST and ALT), -glutamyltranspeptidase (GGTP), total bilirubin, and serum bile acid level remain within the normal range. Alkaline phosphatase rises modestly in the third trimester. The albumin level is lower than in nonpregnant women, and the cholesterol level higher Guntupalli et al, Maryam et al. ${ }^{1,2}$ Thus, elevations in aminotransferases or GGTP signify pathology, and should prompt a search for disease.

Making the correct diagnosis is of paramount importance, as failure to do so can result in morbidity or mortality for not only the mother, but also for her fetus. This study has been carried out to evaluate causes and maternal fetal outcome in pregnancies complicated with jaundice.

\section{METHODS}

This is a prospective study conducted in department of obstetrics and gynecology in a tertiary care referral hospital; Chirayu medical college \& Hospital, Bhopal during one year period from august 2014 to august 2015. During this period 1524 pregnant patients were admitted of which 30 patients with clinical /laboratory evidence of icterus were selected for study.

A detailed history was taken and general, systemic and obstetric examinations were carried out. Liver function tests including serum billirubin, SGOT, SGPT, alkaline phosphatase, Australia antigen, prothrombin time (PT), partial thromboplastin time (PTT), bleeding time (BT), clotting time (CT) and platelet count were done. The maternal outcome was noted in terms of the mode of termination of pregnancy, maternal complications and maternal end result. Fetal outcome was assessed by perinatal morbidity and mortality, neonatal intensive care need.

The results were tabulated and data analysed as frequencies, percentages and descriptive statistics.

\section{RESULTS}

Table 1: Demographic profile of patients $(n=30)$.

\begin{tabular}{|lll|}
\hline Age in years & $\begin{array}{l}\text { Number of } \\
\text { cases }(\mathbf{n}=30)\end{array}$ & percentage \\
\hline $15-20$ & 2 & 6.7 \\
\hline $21-25$ & 20 & 66.66 \\
\hline $26-30$ & 8 & 26.7 \\
\hline Socioeconomic status & \\
\hline Low income group & 18 & 60 \\
\hline $\begin{array}{l}\text { Medium income } \\
\text { group }\end{array}$ & 8 & 26.7 \\
\hline High income group & 4 & 13.3 \\
\hline Residence & & \\
\hline Urban & 22 & 73.3 \\
\hline Rural & 8 & 26.7 \\
\hline ANC status & & \\
\hline booked & 2 & 6.7 \\
\hline unbooked & 28 & 93.3 \\
\hline Gravida & & 66.66 \\
\hline 1 & 20 & 26.7 \\
\hline 2 & 8 & 6.7 \\
\hline 3 & 2 & 73.3 \\
\hline Gestational age & & 26.7 \\
\hline term & 22 & \\
\hline preterm & 8 & \\
\hline & & \\
\hline
\end{tabular}

Table 1 shows the peak age of incidence between 21-25 years $(66.6 \%)$ and majority were primigravida $(66.6 \%)$. All cases were in third trimester of pregnancy, $93.3 \%$ were unbooked, $73.3 \%$ were term, $60 \%$ were of lower socioeconomic status and $73.3 \%$ were urban.

Table 2 shows that all patients presented with jaundice at the time of admission. Pruritus was the most common presenting symptom present in $60 \%$ of patients. Other presenting complaints were nausea, high $\mathrm{BP}$, abdominal pain and petechiae.

Table 3 shows viral Hepatitis was the most important cause of jaundice in this study found in $46.7 \%$ of cases. Preeclampsia and ICP were other causes of jaundice in this study. Hepatitis B was the most common cause of acute hepatitis $(26.7 \%)$ and incidence of hepatitis $\mathrm{E}$ was $13.3 \%$ in our study. Maternal mortality was found in 1 
case of hepatitis E complicated with hepatic encephalopathy and coagulopathy.

Table 2: Clinical presentation at the time of admission $(\mathbf{n}=\mathbf{3 0})$.

\begin{tabular}{|lll|}
\hline Signs and symptoms & $\begin{array}{l}\text { Number of } \\
\text { cases }\end{array}$ & percentage \\
\hline Nausea /vomiting & 14 & 46.67 \\
\hline Pruritus & 18 & 60 \\
\hline $\begin{array}{l}\text { Yellow discoloration } \\
\text { of skin, eye \& urine }\end{array}$ & 20 & 60.67 \\
\hline Abdominal pain & 7 & 23.33 \\
\hline Pallor & 25 & 83.33 \\
\hline Icterus & 30 & 100 \\
\hline Edema & 9 & 30 \\
\hline Preeclampsia & 10 & 33.33 \\
\hline Petechiae & 6 & 20 \\
\hline
\end{tabular}

Table 3: Aetiology of jaundice in pregnancy $(n=30)$.

\begin{tabular}{|lll|}
\hline Aetiology of jaundice & $\begin{array}{l}\text { Number of } \\
\text { cases }\end{array}$ & percentage \\
\hline HELLP & 4 & 13.3 \\
\hline PIH & 10 & 33.3 \\
\hline $\begin{array}{l}\text { ICP(intrahepatic } \\
\text { cholestasis of } \\
\text { pregnancy) }\end{array}$ & 2 & 6.7 \\
\hline Hepatitis A & 2 & 6.7 \\
\hline Hepatitis B & 8 & 26.7 \\
\hline Hepatitis E & 4 & 13.3 \\
\hline $\begin{array}{l}\text { Cirrhosis liver } \\
\text { Acute fatty liver of } \\
\text { pregnancy }\end{array}$ & 0 & 0 \\
\hline
\end{tabular}

Table 4: Maternal complications.

\begin{tabular}{|lll|}
\hline $\begin{array}{l}\text { Maternal } \\
\text { complication }\end{array}$ & $\begin{array}{l}\text { Number of } \\
\text { cases }\end{array}$ & percentage \\
\hline $\begin{array}{l}\text { Preeclampsia- } \\
\text { Eclampsia }\end{array}$ & 10 & 33.3 \\
\hline Preterm labour & 8 & 26.7 \\
\hline ARF & 4 & 13.3 \\
\hline DIC & 6 & 20 \\
\hline PPH & 18 & 60 \\
\hline Encephalopathy & 1 & 3.33 \\
\hline Fever & 10 & 33.3 \\
\hline Multiorgan failure & 4 & 13.3 \\
\hline ICU admission & 30 & 100 \\
\hline $\begin{array}{l}\text { Blood/Blood products } \\
\text { transfusion }\end{array}$ & 18 & 60 \\
\hline Shock & 2 & 6.7 \\
\hline Maternal death & 1 & 3.33 \\
\hline
\end{tabular}

Table 4 shows that all patients were kept in ICU for intensive monitoring. PPH was most common maternal complication in $60 \%$ of patients. $60 \%$ of patient received blood and component therapy and $13.3 \%$ developed multiorgan failure. There was 1 maternal death in our study.

Table 5: Fetal complications.

\begin{tabular}{|lll|}
\hline Fetal complication & $\begin{array}{l}\text { Number of } \\
\text { cases }\end{array}$ & percentage \\
\hline Preterm & 8 & 26.7 \\
\hline IUFD & 4 & 13.3 \\
\hline $\begin{array}{l}\text { Meconium stained } \\
\text { liquor }\end{array}$ & 12 & 40 \\
\hline Uneventful & 2 & 6.7 \\
\hline $\begin{array}{l}\text { Premature rupture of } \\
\text { membranes }\end{array}$ & 5 & 16.66 \\
\hline $\begin{array}{l}\text { Fetal growth } \\
\text { restriction }\end{array}$ & 2 & 6.7 \\
\hline
\end{tabular}

Table 5 shows that out of 30 patients, 12 had spontaneous onset of labour. All delivered vaginally of which 8 (26.7\%) were preterm of which 2 died, 4 (13.3\%) were IUFD, $12(40 \%)$ had fetal distress with meconium stained liquor, 5 (16.6\%) had PROM, 2 (6.7\%) had fetal growth restriction and $2(6.7 \%)$ delivered uneventfully.

\section{DISCUSSION}

Liver disease in pregnancy can manifest as a benign disease with abnormal elevation of liver enzyme levels and a good outcome, or it can manifest as a serious entity affecting hepatobiliary function and resulting in liver failure and death to the mother and her fetus. There are no clinical markers that predict the course of a pregnancy and the pathophysiologic mechanisms are not always understood. The overall mortality attributed to liver disorders in pregnancy has dramatically decreased in the past few years because of clinicians' understanding of the physiologic changes that occur during pregnancy, their vigilance in recognizing clinical and laboratory abnormalities, identifying the aetiology and its effective management in a timely manner. A coordinated team approach that involves the primary care physician, obstetrician, hepatologist, is often required to promote good maternal and fetal outcomes.

This study was done in department of Obstetrics and Gynecology in Chirayu medical college from August 2014 to August 15. During this period 1524 pregnant patients were admitted of which 30 patients with clinical/laboratory evidence of icterus was included for study.

The incidence of liver disorders in pregnancy varies in different parts of the world. Liver disease in pregnancy can present with subtle changes in liver biochemical profile or with fulminant hepatic failure (FHF). The overall incidence of liver disorder in pregnancy in our institution $(1.96 \%)$ ) was comparable with incidence of $0.4 \%$ in study of Acharya $\mathrm{N}$ et al and $0.3 \%$ in Oladokunet al study. ${ }^{3,4}$ Liver disorders affect at younger age group of patients, the peak age being 21-25 years 
$(66.6 \%)$ in our study. Majority $(66.6 \%)$ of affection was found in primigravida in third trimester of pregnancy. Study done by Aparajita et al showed incidence of $52.9 \%$ in younger age group and $51 \%$ were primigravidas. ${ }^{5}$ In our study, $93.3 \%$ patients were unbooked, $73.3 \%$ were term, $60 \%$ were of lower socioeconomic status and $73.3 \%$ were urban.

Jaundice as a result of Viral Hepatitis was most important cause in our study; was found in $46.7 \%$ of cases. Preeclampsia $33.33 \%$ and ICP $6.7 \%$ were other causes found. Cholestatic jaundice was found to be the most common cause $(54.9 \%)$ of liver dysfunction associated with pregnancy in Aparajita et al study.

All patients presented with jaundice at time of admission. Pruritus was most common presenting symptom present in $60 \%$ of patients. Other presenting complaints were nausea, high BP, abdominal pain and petechiae. Incidence of Pruritus is consistent with studies of Aparajita et al they found it in $76.5 \%$ of cases. ${ }^{5}$

Hepatitis B was the most common cause of acute hepatitis $(26.7 \%)$ and incidence of hepatitis $\mathrm{E}$ was $13.3 \%$ in our study; maternal mortality was found in 1 case of hepatitis E complicated with hepatic encephalopathy and coagulopathy. Hepatitis $\mathrm{E}$ was the most common cause of acute hepatitis in Aparajita et al study. ${ }^{5}$ It was commonly associated with FHF and high maternal and perinatal morbidity and mortality with $2 \%$ patients developing FHF in Kumar A, Beniwal et al study and $16.66 \%$ maternal mortality in study of Reddy et al. ${ }^{6,7}$

All patients were kept in ICU for intensive monitoring. PPH was most common maternal complication in $60 \%$ of patients for which uterine balloon temponade was done and blood products (FFP) were given. There was 1 maternal death in our study. Nearly $2 \%$ of the patients required ICU admission in Aparajita et al study study. ${ }^{5}$ Intensive care is a necessity in these cases and various studies had ICU admissions ranging from $4.3 \%$ to $62.6 \%$ in Pollock et al study. ${ }^{8}$

Of 30 patients, 12 had spontaneous onset of labour. All delivered vaginally of which $8(26.7 \%)$ were preterm of which 2 died, 4 (13.3\%) were IUFD, 12 (40\%) had fetal distress with meconium stained liquor, 5 (16.6\%) had PROM, $2(6.7 \%)$ had fetal growth restriction and 2
(6.7\%) delivered uneventfully. In Aparajita et al study (5), 94.2\% were live births and 5.7\% fresh still birth and incidence of prematurity was $13.7 \%$.

Our present study reemphasizes on the fact that there is increased maternal and fetal morbidity and mortality in pregnancy complicated with jaundice and hence, requires early interventions as timely inductions, $\mathrm{PPH}$ prophylaxis assuring availability of adequate blood products for overcoming associated coagulopathy and intensive monitoring of both mother and fetus which requires team work of obstetrician, neonatologist, intensivist, hepatologist and haematologist.

\section{Funding: Not required}

Conflict of interest: None declared

Ethical approval: The study was approved by the Institutional Ethics Committee

\section{REFERENCES}

1. Guntupalli SR, Steingrub J. hepatic disease and pregnancy- an overview of diagnosis and management. Crit Care Med. 2005;33:332-3.

2. Salman MI. Changes in liver functions tests during pregnancy. $\mathrm{J}$ of al-anbar university forpure science. 2009;3(1).

3. Acharya N, Acharya S, Shukla S, Athvale R, Shaveta. Study of Jaundice in Pregnancy. Glb J of Med research. 2013;13:25-9.

4. Oladokun A, Otegbayo JA, Adeniyi AA maternal and fetal outcomes of jaundice in pregnancy at the University College Hospital, Ibadan. Niger J Clin Pract. 2009; 12(3):277-80.

5. Dsouza AS, Gupta G, Katumalla FS, Goyal S. Maternal and fetal outcome in liver diseases of pregnancy-A tertiary hospital experience. International Journal of Scientific and Research Publications. 2015;5(9).

6. Kumar A, Beniwal M, Kar P, Sharma JB, Murthy NS. Hepatitis E in pregnancy. Int J Gynecol Obstet India. 2004;7:11-5.

7. Reddy MG, Prabhakar GC, Sree V. Maternal and fetal outcome in jaundice complicating pregnancy. J NTR Univ Health Sci. 2014;3:231-3.

8. Acharya N, Acharya S, Shukla S, Athvale R. Study of Jaundice in Pregnancy. Glb $\mathrm{J}$ of Med research. 2013;13:25-9.

Cite this article as: Sharma S, Aherwar R, Jawade S. Maternal and fetal outcome in jaundice complicating pregnancy: a prospective study. Int J Reprod Contracept Obstet Gynecol 2016;5:1084-7. 